\title{
“ALÉM DO VISÍVEL” ÁREAS DINÂMICAS EM JATAÍ-GO
}

\author{
"BEYOND THE VISIBLE" \\ DYNAMIC AREAS IN JATAÍ-GO-BRAZIL
}

\author{
“ADEMÁS DEL VISIBLE” \\ ÁREAS DINÁMICAS EN JATAÍ-GO-BRASIL
}

\author{
Márcio Rodrigues Silva \\ Mestre em Geografia - IESA/UFG. Doutorando em Geografia - IESA/UFG. \\ icanto.net@gmail.com site www.icanto.net
}

\section{Resumo}

O presente trabalho analisa o espaço urbano de Jataí, cidade localizada no Sudoeste do Estado de Goiás, levando em consideração aspectos de ordem econômica na constituição deste tecido urbano. A proposta em questão identifica áreas de destaque na cristalização urbana de Jataí, as quais denominamos áreas dinâmicas. Propomos um debate sobre esta configuração, buscando cooperar na compreensão do processo de produção da cidade, fazendo uso de uma análise que cruza informações da expansão urbana ligadas diretamente com a dinâmica produzida por este movimento. Através deste debate chegamos a análises que vão "além do visível” da paisagem urbana revelando uma dinâmica que cria no tecido urbano áreas que não se limitam ao traçado original dos bairros e que em muitas situações o negam.

Palavras chave: Espaço Urbano; Paisagem Urbana; Jataí-GO.

\begin{abstract}
The present text analyzes the urban space of Jataí. The city of Jataí is located in the Southwest of Goiás State in Brazil. In this analysis we consider aspects of economic order in the constitution of this city. The proposal in question identifies areas of prominence in the urban crystallization of Jataí. This areas are called of: The "Dynamic Areas". We debate this subject to cooperate in the understanding of the process of production of the city. This analysis is made by studies of the movement produced by urban expansion. Through this debate we find answers that go "beyond the visible" of the urban landscape, disclosing a dynamics that creates in the urban cloth areas that are not limited to the original tracing of the quarters and that in many situations they deny it.
\end{abstract}

Key-words: Urban Space; Urban Landscape; Jataí-GO-Brazil. 


\section{Resumen}

El trabajo actual analiza el espacio urbano de Jataí, ciudad del Sudoeste del Estado de Goiás en Brasil, teniendo en cuenta los aspectos de la orden económica en la constitución de esta estructura urbana. La propuesta en el tema identifica áreas de prominencia en la cristalización urbana de Jataí, cuál nosotros llamamos "áreas dinámicas”. Proponemos un debate sobre esta configuración para cooperar en el conocimiento del proceso de la producción de la ciudad. Utilizamos un análisis que cruza la información de la expansión urbana y su dinâmica. A través de este debate llegamos a los análisis que se van "además del visible" del paisaje urbano que revela una dinámica que creaba áreas urbanas que no están limitados al plan original de los vecindarios y que en muchas situación lo niega.

Palabras llaves: Espacio Urbano; Paisaje Urbana; Jataí - GO-Brasil.

\section{“ALÉM DO VISÍVEL” ÁREAS DINÂMICAS EM JATAÍ-GO}

“... e caiu a chuva, transbordaram os rios, sopraram os ventos e deram com ímpeto contra aquela casa, que não caiu, porque fora edificada sobre a rocha." Mateus 7:25

O presente texto analisa o espaço urbano de Jataí (Figura 1), cidade situada no Sudoeste do Estado de Goiás que origina-se na primeira metade do século XIX sendo fruto da busca por novas áreas para desenvolvimento da agropecuária e que atualmente ocupa lugar de grande relevância na economia do Estado. Jataí é, também, destaque nacional na produção de grãos, o que passa a ocorrer principalmente a partir da década de 1970, com a chegada e posterior consolidação da moderna agricultura no município. Com área urbana aproximada de $24 \mathrm{~km}^{2}$ a cidade se expandiu marcada por contrastes que revelam a lógica da sociedade capitalista. 
Figura 1: Localização da área de estudos
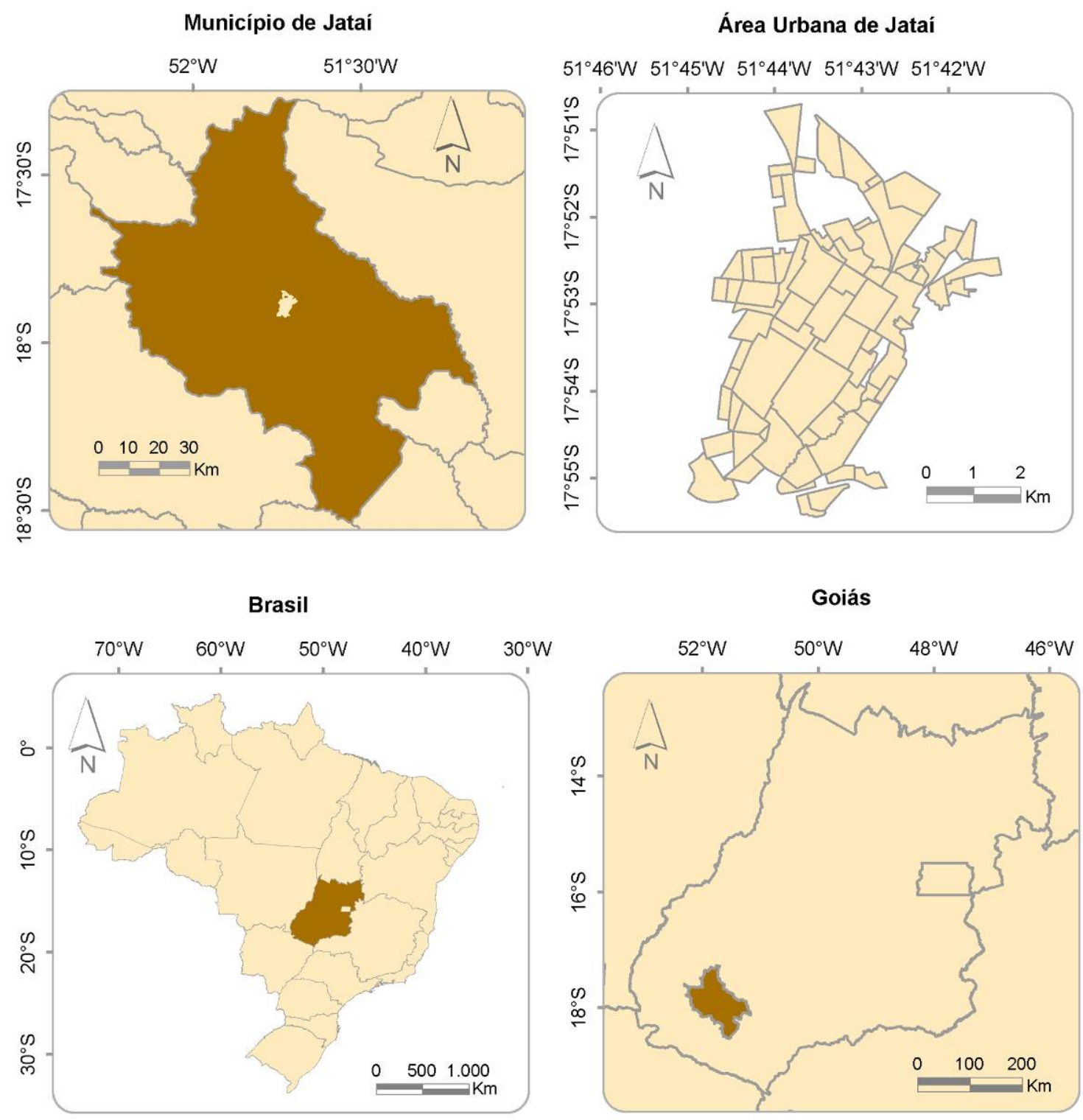

Discutimos alguns dados referentes à dissertação de mestrado apresentada ao Programa de Pesquisa e Pós-Graduação em Geografia do Instituto de Estudos SócioAmbientais da UFG e defendida no ano de 2005. A proposta em questão identifica áreas de destaque na cristalização urbana de Jataí, as quais denominamos de áreas dinâmicas. Propomos um debate sobre esta configuração, buscando cooperar na compreensão do processo de produção da cidade, fazendo uso de uma análise que cruza informações da 
expansão urbana ligadas diretamente com a dinâmica produzida por este movimento.

Dinâmica esta que cria no tecido urbano áreas que não se limitam ao traçado original dos bairros e que em muitas situações o negam. É através deste debate que caminhamos rumo a uma análise que vá além do aspecto visível da paisagem, chegando às áreas mencionadas e nas suas influências.

\section{CONSIDERAÇÕES INICIAIS}

Atualmente, é comum ver um cenário urbano marcado por problemas como a falta de emprego, a precariedade do transporte, do saneamento, da saúde, etc. Essa situação não é desconhecida e torna-se cada vez mais perceptível à medida que cresce a urbanização. Como corrobora Santos (1993, p.95), “com diferença de grau e intensidade, todas as cidades brasileiras exibem problemáticas parecidas”. A ocupação do solo urbano exige atualmente um sério controle através de órgãos reguladores, como as prefeituras em escala local, sendo fundamental o papel do poder público na busca de soluções para o cenário urbano.

Sabemos, então, que instrumentos que possam direcionar um processo de crescimento que atenda todas as esferas sociais são imprescindíveis na busca pelo desenvolvimento das cidades. Em um destes instrumentos, o Plano Diretor Urbano implantado em Jataí, observamos metas que, ao serem alcançadas, resultarão num espaço urbano mais justo e numa melhoria da qualidade de vida da população local, uma vez que nele se prevê

[...] garantir o equilíbrio entre o crescimento demográfico/econômico e a qualidade de vida e bem-estar da população na área urbana [...] bem como [...] assegurar as condições gerais para o desenvolvimento da produção, do comércio e dos serviços e, particularmente para a plena realização dos direitos dos cidadãos como o direito à saúde, à educação, ao saneamento básico, ao trabalho e à moradia, ao transporte coletivo, à segurança, à informação, ao lazer e à qualidade ambiental e à participação no planejamento. (JATAÍ-PLANO DIRETOR URBANO, 2001, p.1)

A situação de Jataí não é uma exceção às observações de Santos (1993), problemas urbanos estão presentes em sua realidade. É aqui que o Geógrafo deve atuar de forma a auxiliar na busca de soluções para os problemas que, freqüentemente, caminham ao lado do processo de expansão urbana. 
Como forma de embasar as decisões públicas referentes ao planejamento urbano e ainda dar suporte a novos estudos que visem contribuir para o desenvolvimento, e não somente crescimento, da cidade este trabalho objetiva analisar o espaço urbano de Jataí-GO. Tentamos fazer esta análise através do cruzamento de informações que ao serem interligadas revelam que o visível nem sempre é o real, necessitando, assim, uma investigação mais detalhada.

Consideramos que este trabalho, assim como outros estudos sobre a cidade, é de fundamental importância para fornecer dados e informações ao poder público municipal, bem como à sociedade em geral, objetivando a promoção do debate, do questionamento e, acima de tudo, de ações que promovam “[...] um desenvolvimento urbano autêntico, sem aspas, [que] não se confunde com uma simples expansão do tecido urbano” (SOUZA, 2003, p.101).

\section{O CONTEXTO: DINÂMICA ECONÔMICA E ESPAÇO URBANO}

O contexto desta análise considera que desenvolvimento econômico e crescimento urbano estão intimamente ligados. É o que pode ser verificado na cidade de Jataí quando se cruza os dados referentes a implantação de loteamentos (Tabela 1 e Figura 2) com os de instalação de atividades econômicas (Tabela 2, Quadro 1 e Figuras 4 a 9). Na década de 1980 encontramos o maior número de loteamentos implantados no período da pesquisa ${ }^{1}$ (décadas de 1970 a 2000), o que coincide com o período mais expressivo em termos de instalação de atividades econômicas no município.

\footnotetext{
${ }^{1}$ Para mais informações acerca da pesquisa mencionada ver: SILVA, Márcio Rodrigues. Encontros e desencontros: estudo do espaço urbano de Jataí-GO. 2005, 113p. Dissertação (Mestrado em Geografia) - Universidade Federal de Goiás, Instituto de Estudos Sócio-Ambientais, Goiânia, 2005.
} 
Tabela 1: Jataí-GO: Implantação de Loteamentos - Conjuntos Habitacionais Financiados e Conjuntos Habitacionais/Loteamentos de Baixa Renda

\begin{tabular}{cccccccc} 
Década & Até 1959 & $\mathbf{1 9 6 0}$ & $\mathbf{1 9 7 0}$ & $\mathbf{1 9 8 0}$ & $\mathbf{1 9 9 0}$ & $\mathbf{2 0 0 0}$ & Total \\
\hline $\begin{array}{c}\text { Total Geral de } \\
\text { Loteamentos } \\
\text { Implantados }\end{array}$ & 5 & 19 & 11 & 22 & 18 & 7 & $\mathbf{8 2}$ \\
\hline $\begin{array}{c}\text { Conj. Habit. } \\
\text { Financiados }\end{array}$ & 1 & 3 & 3 & 2 & 9 \\
\hline $\begin{array}{c}\text { Conj. } \\
\text { Habit/Loteam } \\
\text { Baixa Renda }\end{array}$ & & & 2 & 7 & 2 & 11 \\
\hline
\end{tabular}

Fonte: Prefeitura Municipal de Jataí; MELO, N. A. (2003). Organização dos Dados: Márcio Rodrigues Silva. Os dados da década de 2000 referem-se ao período de 2000-2003.

Quadro 1: Jataí-GO: Atividades econômicas instaladas - Até 1959-2000

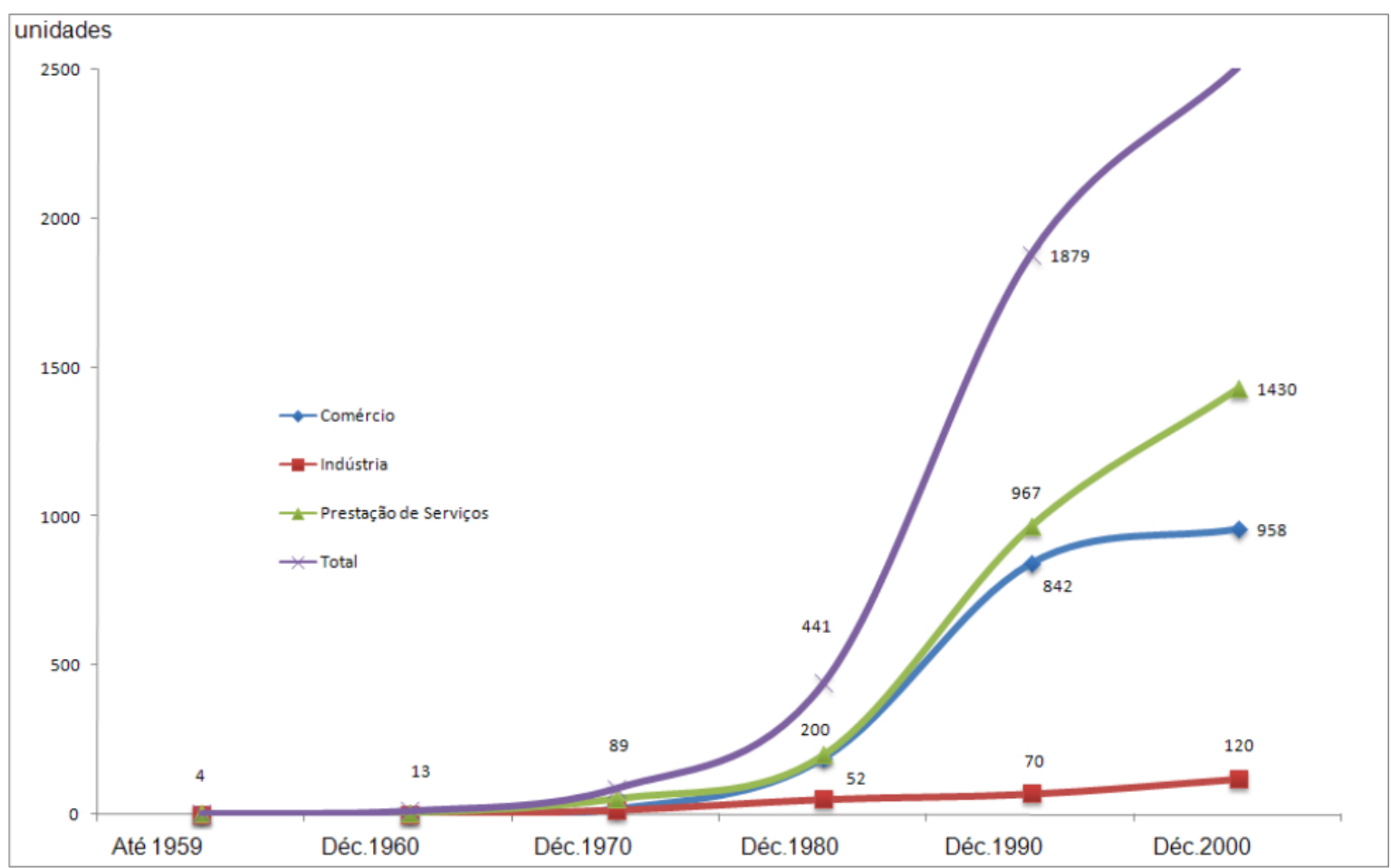

Fonte: Prefeitura Municipal de Jataí: SEGEF-Secretaria de Gestão Fiscal, 2004.

O Artigo $3^{\circ}$, do Capítulo II, do Plano Diretor Urbano da cidade de Jataí, ao tratar sobre o parcelamento do solo urbano, estabelece o seguinte em uma de suas diretrizes:

[...] Direcionar o crescimento da cidade, a médio e longo prazo para a região oeste do perímetro urbano, que oferece boas condições topográficas para a urbanização e com a correspondente expansão da rede viária e de infraestrutura básica. (JATAÍ-PLANO DIRETOR URBANO, 2003) 
Tal determinação vai ao encontro do crescimento urbano de Jataí. Partindo do núcleo original as áreas a oeste, com relevo adequado e sem barreiras ao crescimento urbano, sempre tiveram prioridade no que se refere à implantação de novos loteamentos. Conforme descrição da Figura 3 observam-se as possibilidades de expansão urbana. Salienta-se que, em relação à porção leste da cidade, as condições não são favoráveis à expansão, em áreas significantes, uma vez que nela situa-se o $41^{\circ}$ Batalhão de Infantaria Motorizada do Exército Brasileiro, ocupando significativa área e constituindo-se, juntamente com condições topográficas não muito favoráveis, em barreira ao crescimento na porção oriental. 


\section{AATELIÊ GEOGRÁFICO

Figura 2: Jataí-GO: Expansão urbana - Implantação de loteamentos

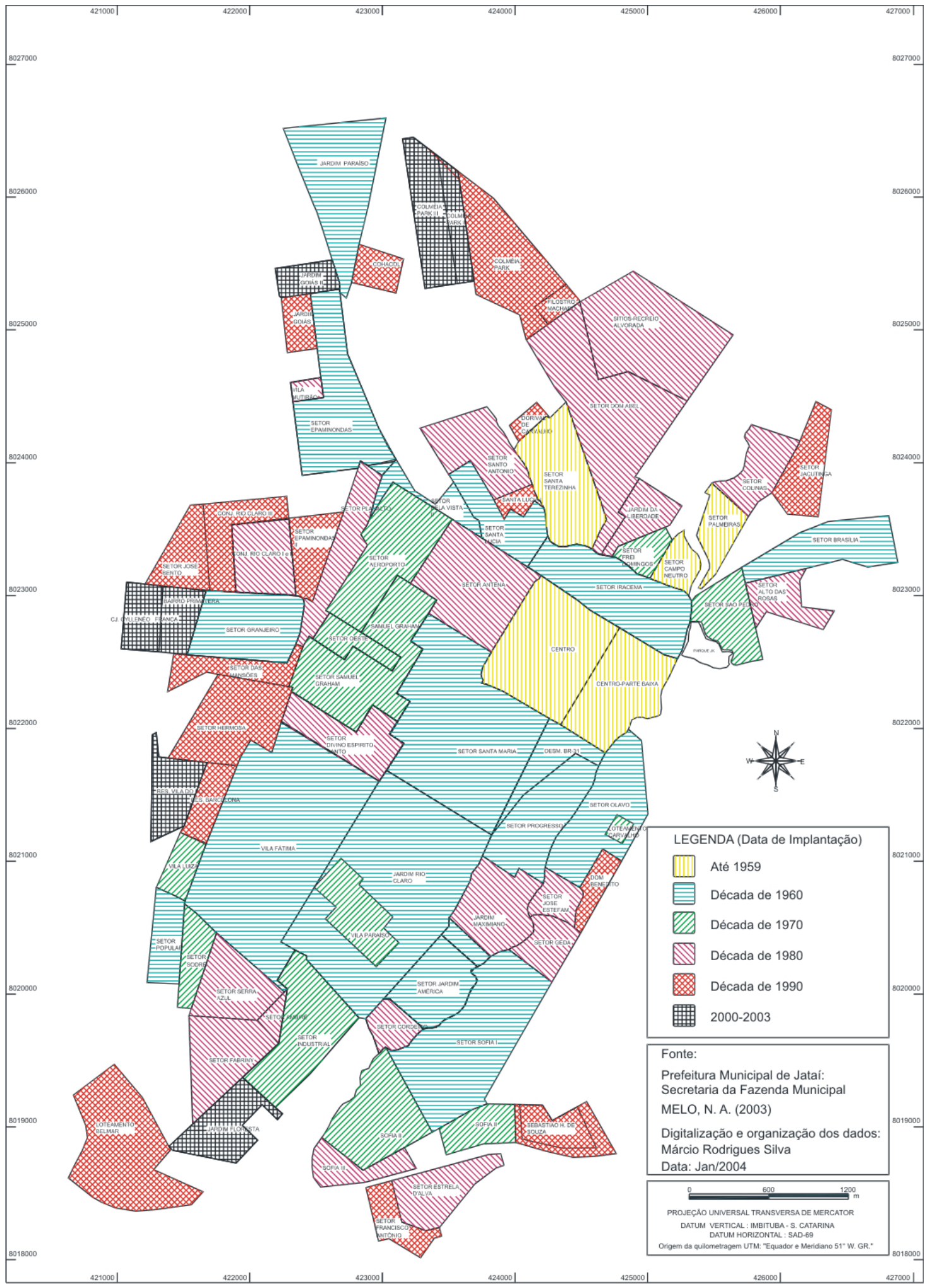


Figura 3: - Jataí-GO: Possibilidades de Expansão da Área urbana

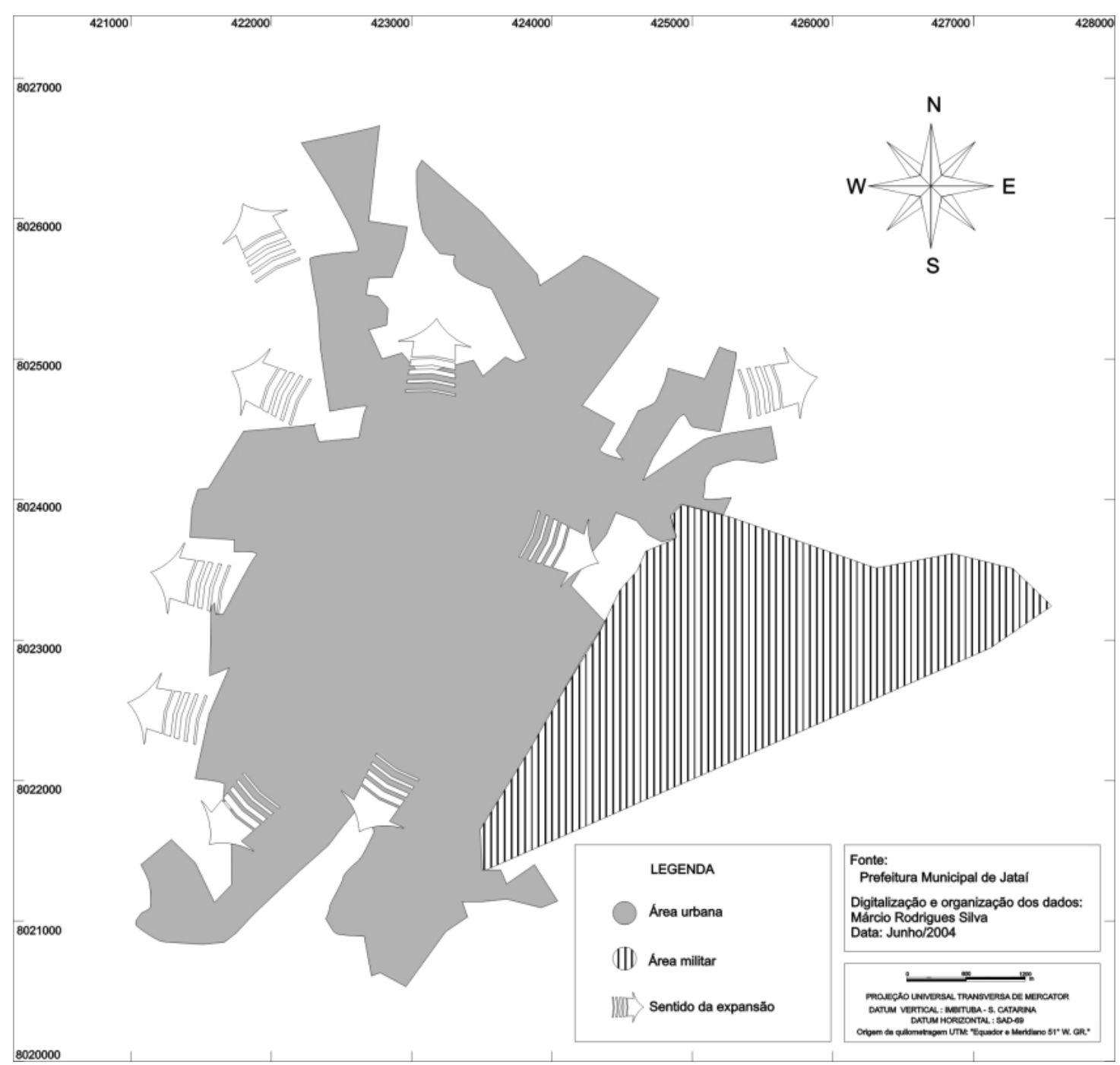

A expansão urbana, com destaque para o período de ascensão da agricultura mecanizada, ofereceu o espaço necessário para a implantação de atividades econômicas que ora vieram atender a demanda impulsionada pela dinâmica da moderna agricultura.

Conforme observa Santos (1998, p. 10-11), as cidades, “[...] podem corresponder a centros de atendimento das necessidades de circulação da produção agrícola ou de atividades industriais de pequena escala de produção”. Neste sentido, no momento em que a produção cresce as atividades terciárias são diversificadas para atender as próprias necessidades internas. As atividades especializadas desenvolvidas na cidade, bem como aquelas voltadas para exportação, “[...] geram um dinamismo local que sustenta um conjunto amplo e variado de atividades para o atendimento da 
demanda local” (SANTOS, 1998, p.13). Esse dinamismo pode ser verificado pelos dados de implantação das atividades econômicas em Jataí (Tabela 2 e Quadro 1).

Tabela 2: Jataí-GO: Atividades Econômicas Cadastradas na Secretaria de Gestão fiscal - Até 1959-2000

\begin{tabular}{ccccc}
\hline Década & Comércio & Indústria & $\begin{array}{c}\text { Prestação de } \\
\text { Serviços }\end{array}$ & Total \\
\hline Até 1959 & 1 & 0 & 3 & 4 \\
1960 & 4 & 2 & 7 & 13 \\
1970 & 19 & 16 & 54 & 89 \\
1980 & 189 & 52 & 200 & 441 \\
1990 & 842 & 70 & 967 & 1879 \\
2000 & 958 & 120 & 1430 & 2508 \\
\hline Total & $\mathbf{2 0 1 3}$ & $\mathbf{2 6 0}$ & $\mathbf{2 6 6 1}$ & $\mathbf{4 9 3 4}$ \\
Geral & & & & \\
\hline
\end{tabular}

Fonte: JATAÍ-GO (2004c).

A demanda local foi ao encontro da afirmação de Lefebvre (1999, p.149):

"Enfim e sobretudo, a cidade e a aglomeração urbana concentram 'serviços””. Fato que pode ser observado no Quadro 1: As décadas de maior crescimento econômico local correspondem aos segundo e terceiro período propostos na pesquisa, quais sejam, a fase de modernização da agricultura, fundamentalmente a partir da década de 1970, e sua consolidação nas décadas posteriores (1980 e 1990). O intervalo ora tratado representa um salto na economia jataiense, com destaque para as atividades prestacionais e comerciais respectivamente. Melo (2003, p. 121) destaca tal alteração no espaço urbano, uma vez que

a produção agrícola moderna produziu mudanças econômicas que se expressam espacialmente na cidade. Esta, ao mesmo tempo, se modificou para atender ao desenvolvimento da produção realizada no campo e pelas suas demandas internas de serviços e equipamentos.

Jataí, enquanto cidade que “[...] concentra não só a população, mas os instrumentos de produção, o capital, as necessidades, os prazeres [e] tudo o que faz com que uma sociedade seja uma sociedade” (LEFEBVRE, 1999, p.49)(Grifo no original) percebe a instalação prioritariamente de estabelecimentos prestadores de serviços.

A cidade, sendo ela mesma uma obra, reúne em si a produção de necessidades e prazeres que concedem sentido à produção. Nela também são 
produzidos, trocados e consumidos os bens (LEFEBVRE, 1999, p.51). Tudo isso requer uma espacialização. Nessa espacialização cristaliza-se o espaço urbano. Nela percebemos que a cidade é “[...] coisa social, na qual são evidentes (tornam-se sensíveis) relações sociais que, tomadas em si não são evidentes [...]”(LEFEBVRE, 1999, p.140) (Grifo no original).

Este conjunto, formado por encontros e desencontros, reflete bem o que Santos (1998, p.23) relata em relação à constituição de "regiões agrícolas”. A formação destas “[...] envolve a necessidade de estabelecimento de cidades de porte compatível com as atividades terciária, relativas à circulação [da produção], bem como a prestação de serviços que viabilizem tal produção”.

A estrutura da sociedade local, que nada mais é do que o reflexo de uma conjuntura ampla com vistas à reprodução do capital, mostra-se articulada com o fenômeno urbano (CASTELLS, 1983, p.43). A urbanização reflete a relação entre sociedade e espaço. Ela é função da organização específica dos modos de produção, bem como da estrutura interna daquele que prevalece (CASTELLS, 1983, p.111). É através desta relação que podemos partir para a delimitação das áreas dinâmicas de Jataí.

\section{AS ÁREAS DINÂMICAS}

Pela análise da espacialização das atividades econômicas (Figuras 4 a 9) na cidade de Jataí, do processo de expansão urbana (Figura 2), e do cruzamento destas informações chegamos à definição de algumas áreas que se destacam no cenário urbano. A definição destas áreas considerou a expansão urbana associada ao desenvolvimento econômico local. Desta forma uma área dinâmica foi delimitada pela existência de atividades econômicas - prestação de serviços, comércio e indústria - dentro da área de expansão urbana de cada década analisada (Figuras 2 e 10 e Tabela 2). Estas áreas apresentam um incremento maior em relação às demais que ora foram loteadas e não ocupadas, ora foram ocupadas, mas, não apresentam dinâmica própria, permanecendo opacas e dependentes de outras partes do tecido urbano. 


\section{AATELIÊ GEOGRÁFICO \\ REVISTA ELETRÓNICA \\ $U F G$ - IESA}

Figura 4: Jataí-GO: Atividades econômicas instaladas até a década de 1959

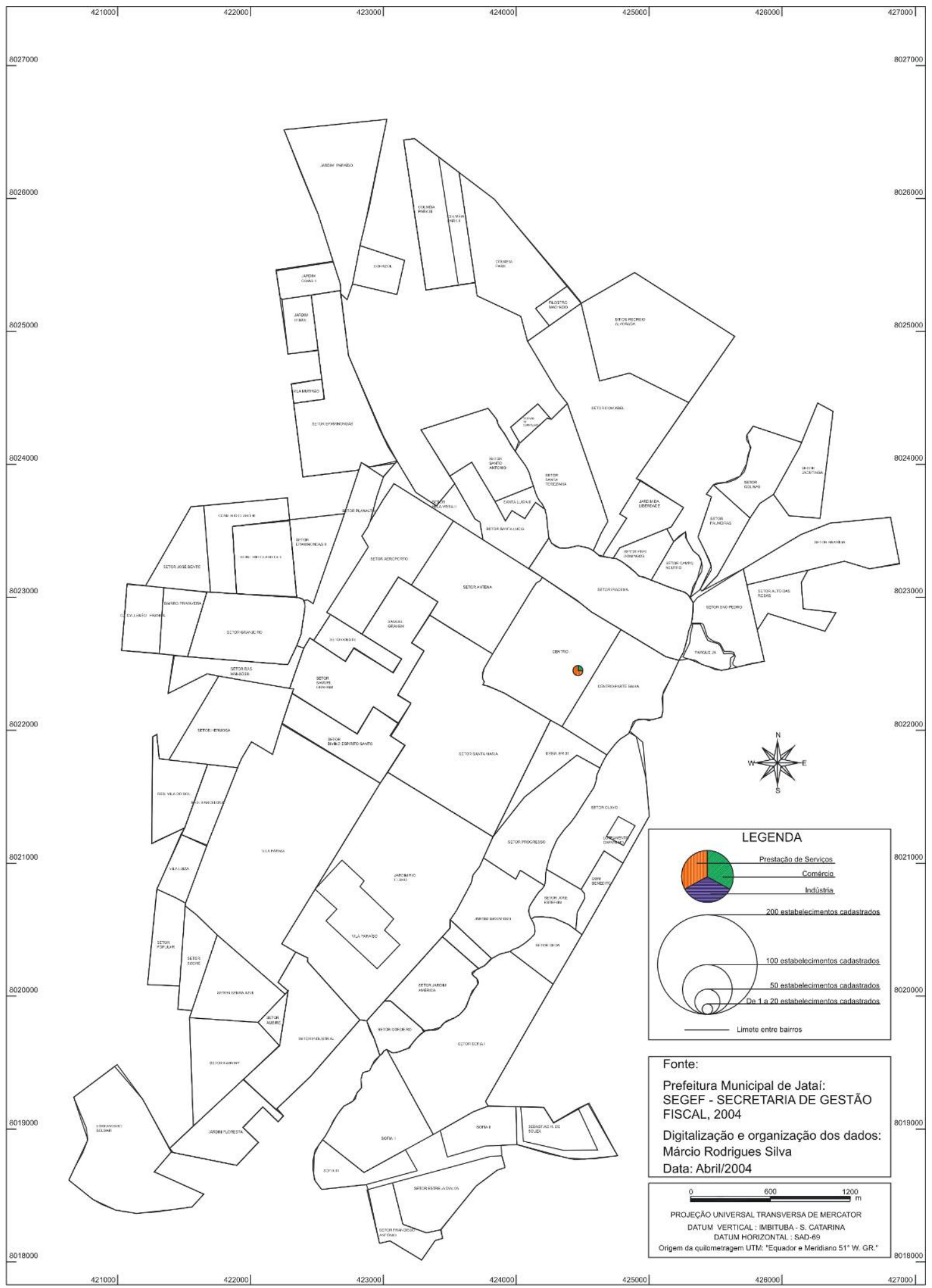




\section{ЉATELIÊ GEOGRÁFICO \\ REVISTA ELETRÓNICA \\ $U F G=1 E S A$}

Figura 5: Jataí-GO: Atividades econômicas instaladas na década de 1960

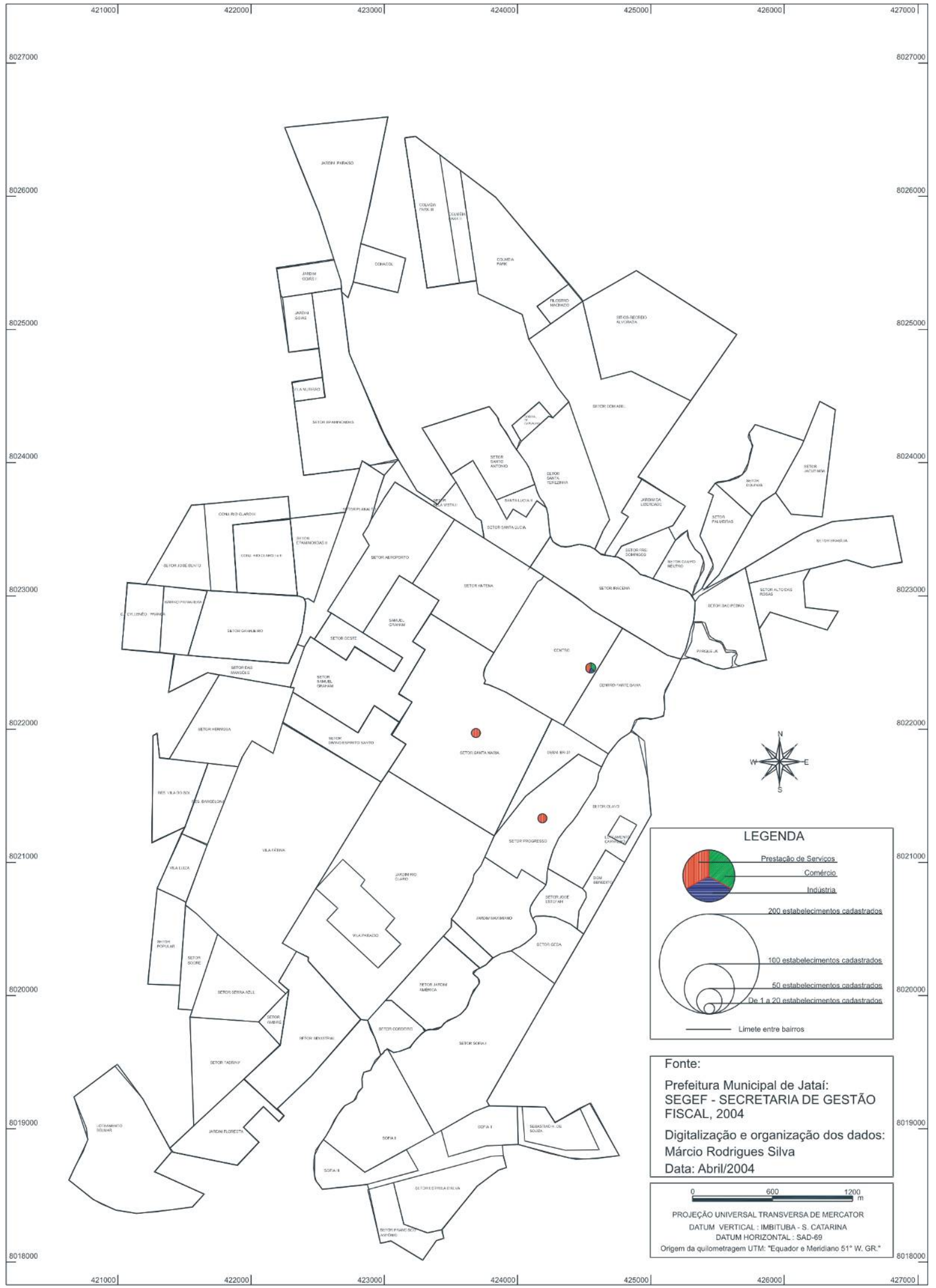




\section{ЉATELIÊ GEOGRÁFICO \\ REVISTA ELETRÓNICA \\ UFG-IESA}

Figura 6: Jataí-GO: Atividades econômicas instaladas na década de 1970

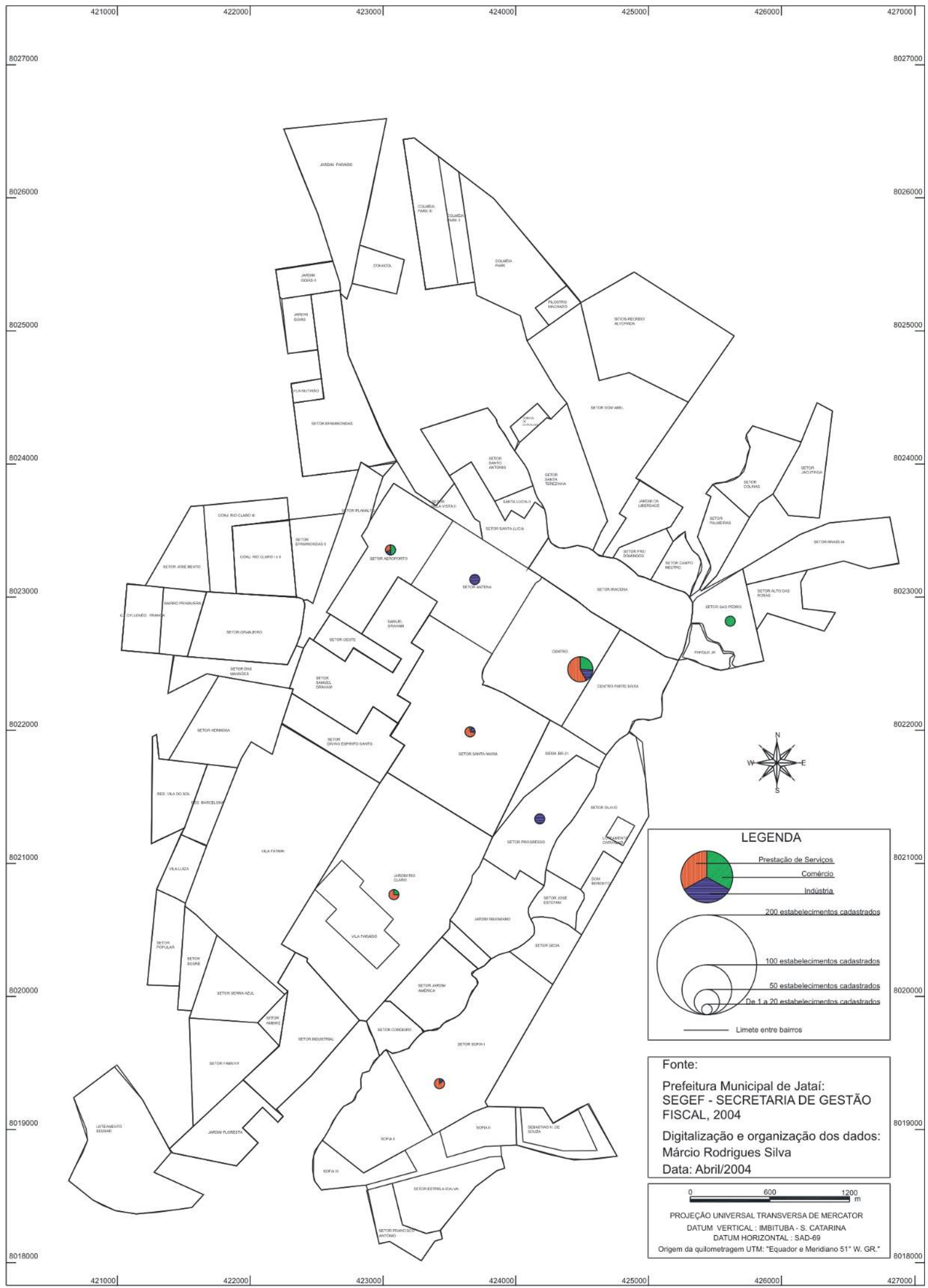




\section{ЉATELIÊ GEOGRÁFICO \\ REVISTA ELETRÓNICA \\ UFG-IESA}

Figura 7: Jataí-GO: Atividades econômicas instaladas na década de 1980

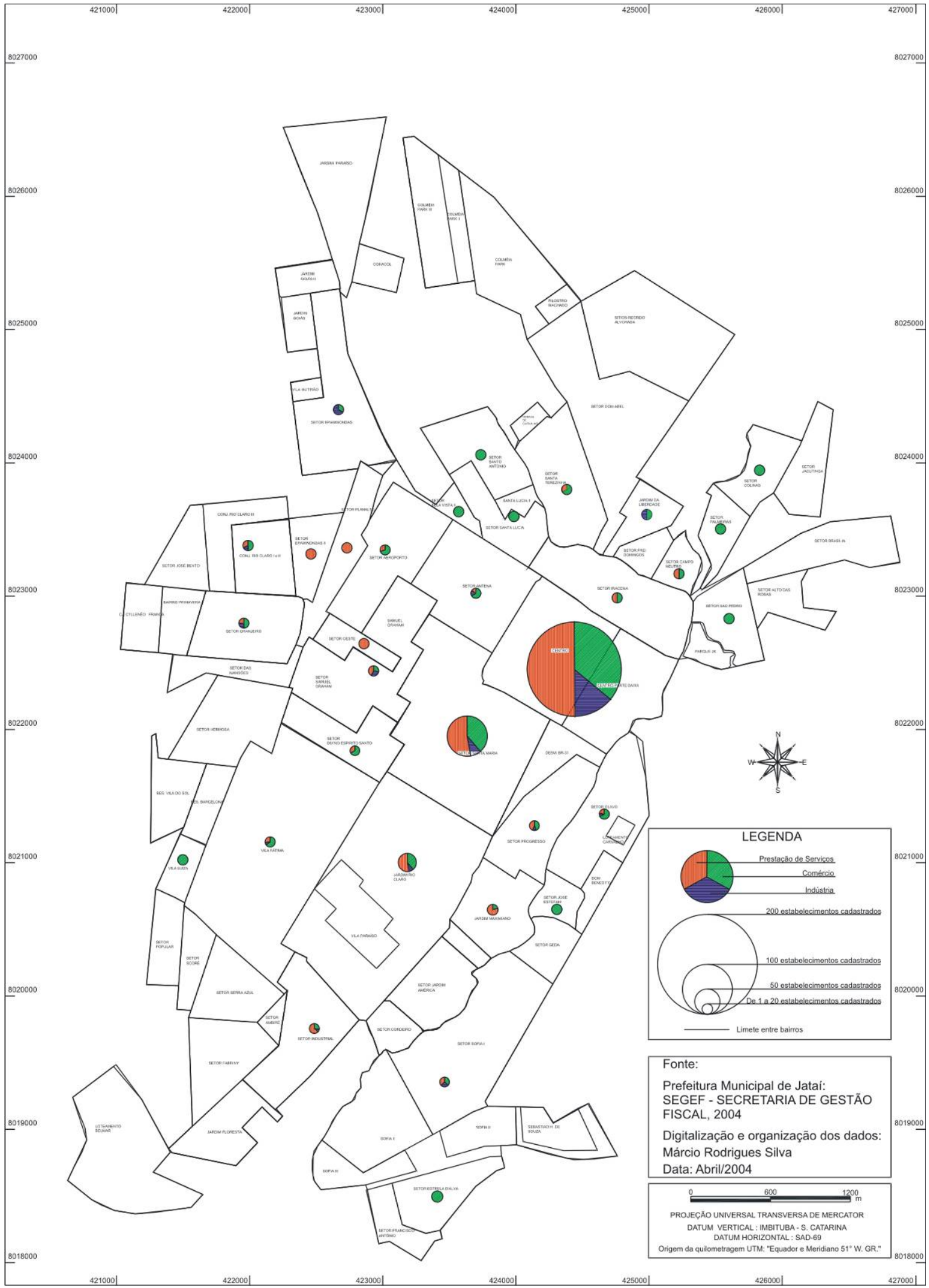




\section{ЉATELIÊ GEOGRÁFICO \\ REVISTA ELETRÓNICA \\ $U F G$ - IESA}

Figura 8: Jataí-GO: Atividades econômicas instaladas na década de 1990

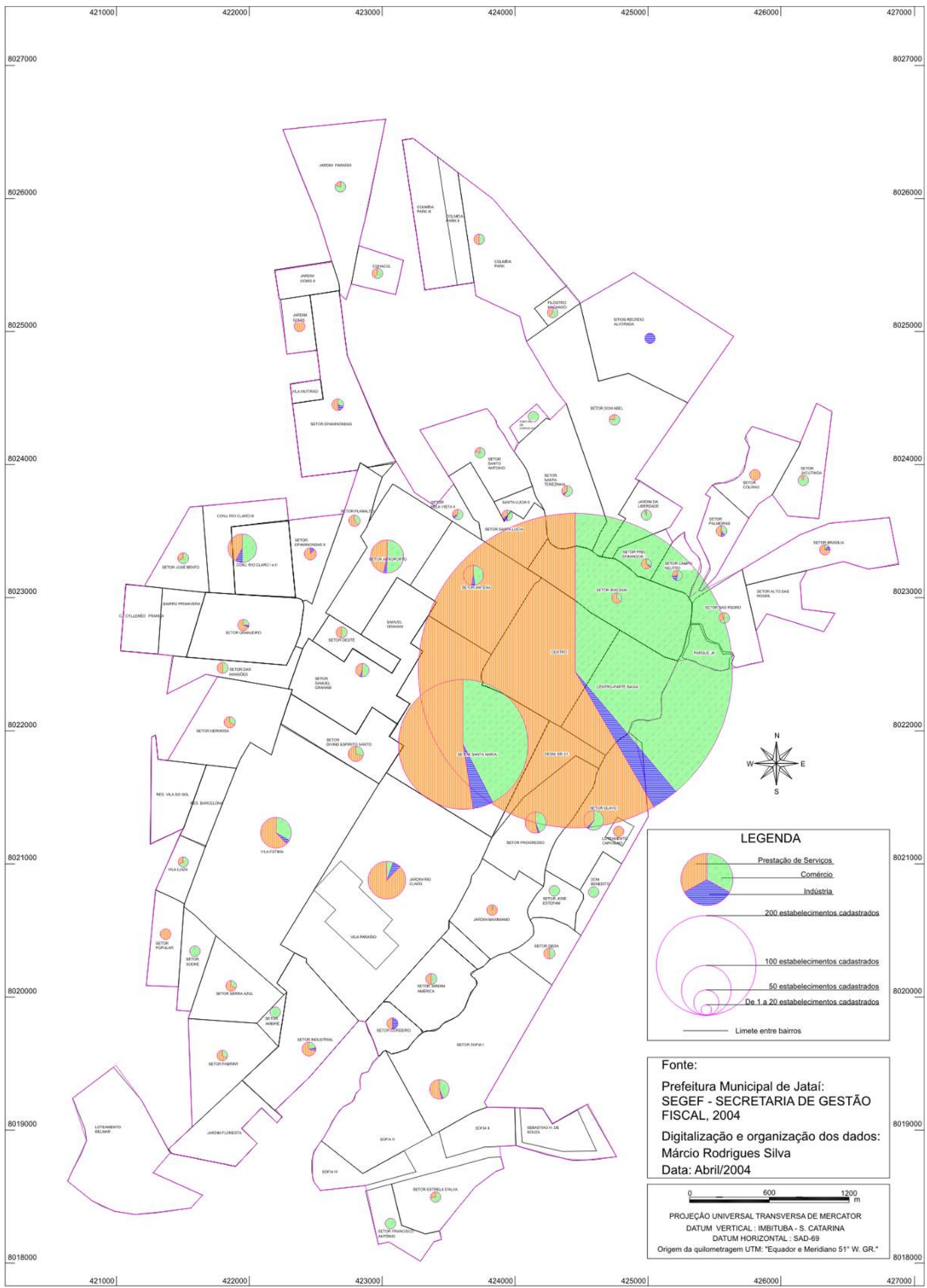




\section{AATELIÊ GEOGRÁfICO REVISTA ELETRÓNICA \\ UFG-IESA}

Figura 9: Jataí-GO: Atividades econômicas instaladas na década de 2000

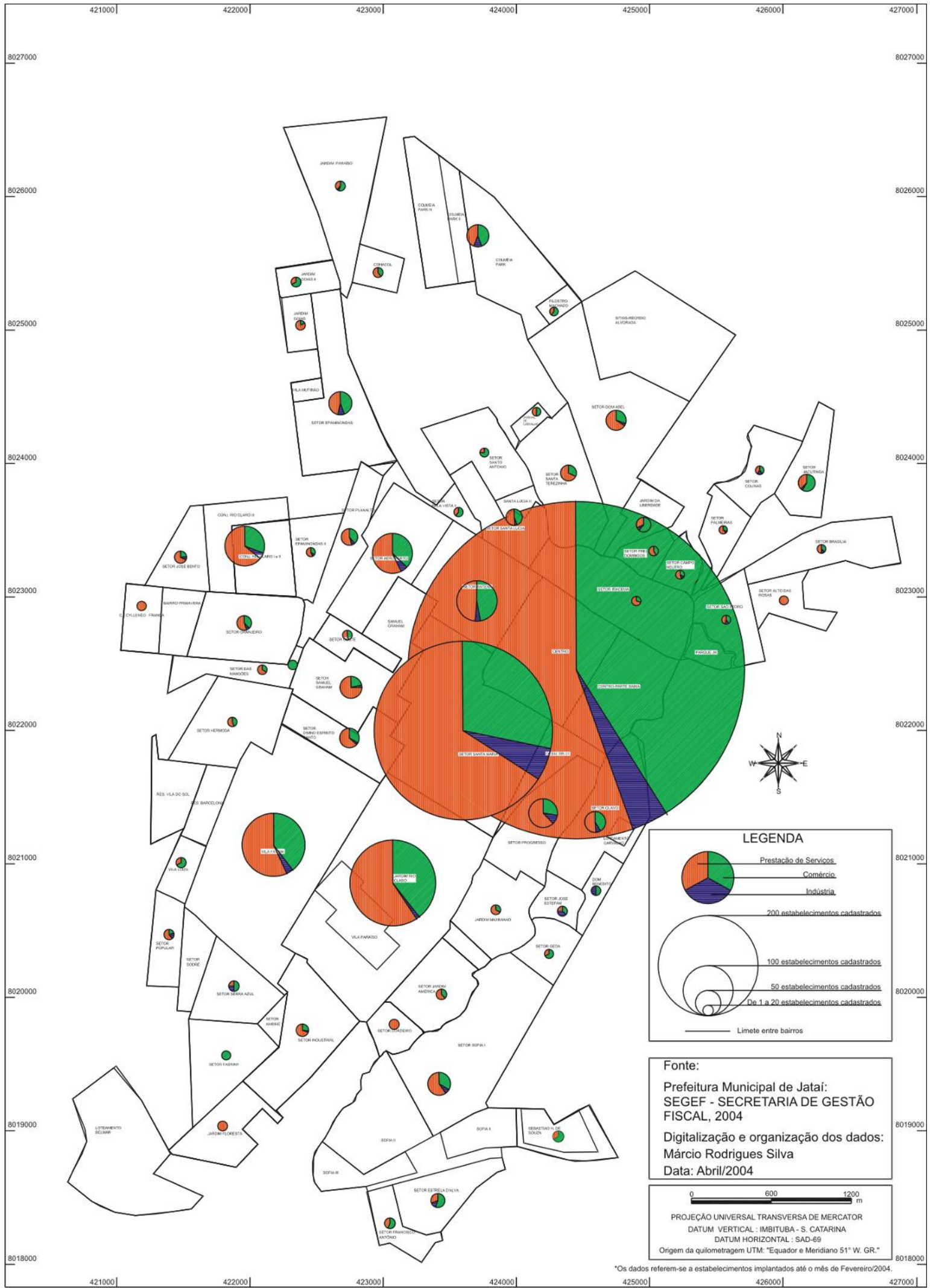




\section{(AATELIÊ GEOGRÁFICO \\ REVISTA ELETRÓNICA \\ UFG-IESA}

Figura 10: Jataí-GO: Áreas dinâmicas: Atividades econômicas x Expansão Urbana

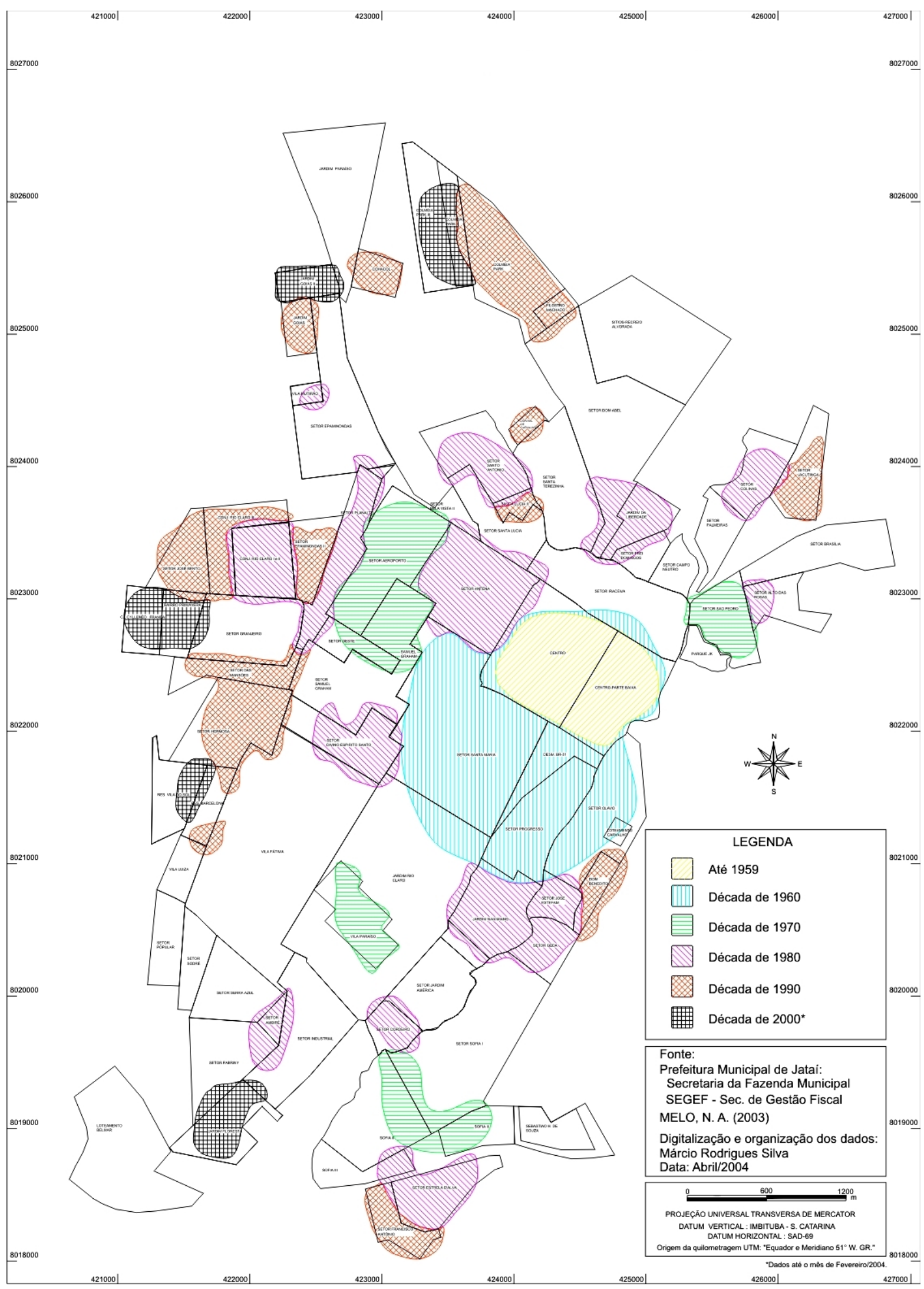


O processo de expansão urbana não foi necessariamente acompanhado, num primeiro momento, de um desenvolvimento nas regiões então ocupadas. O conjunto de fatores necessários à consolidação de um determinado setor da cidade se distribuíram espacialmente conforme a Figura 10.

Partindo da região central da cidade, a mesma de seu núcleo original, verificam-se movimentos de destaque nas direções Sul-Sudoeste e Oeste-Noroeste.

O núcleo original é o centro das atividades econômicas, é o coração da cidade aproximadamente até o final da década de 1950. Esta área expande-se posteriormente na direção Sul-Sudoeste consolidando, na década de 1960, a principal área de concentração de comércio e serviços que se destaca até os dias atuais.

No período de 1970-1980 o espaço urbano percebe um deslocamento de algumas atividades, antes localizadas somente nas áreas centrais, em direção às novas áreas ocupadas.

O processo de desconcentração das atividades centrais segue com mais força na década de 1990. Nesses anos as áreas localizadas a Oeste-Noroeste recebem um maior destaque no cenário urbano. Década marcada pela presença de vários loteamentos/conjuntos habitacionais populares e que marca-se também pelo deslocamento das atividades econômicas com vistas a atender o adensamento populacional característico destes locais.

Na década atual percebe-se um movimento em direção às áreas periféricas da cidade com a implantação de novos loteamentos e conjuntos habitacionais. Uma vez que as áreas intermediárias encontram-se loteadas, não significando necessariamente sua ocupação, o alvo dos loteamentos são as áreas mais distantes do núcleo central.

Embora a região central apresente-se como indispensável ao dinamismo da cidade torna-se nítida a presença de movimentos que tendem a deslocar o centro de decisão para áreas que ofereçam melhores condições de acesso (rede viária principalmente) e maiores perspectivas de desenvolvimento. Esse movimento nos remete às palavras de Castells (1983, p.54) quando destaca o papel do automóvel na contribuição da dispersão urbana. Não significa a decadência da primeira em relação à segunda, seria um movimento de gestação de uma nova área dinâmica . 
Através desta análise temos uma visão real da “cidade viva” que se distingue da cidade legal, determinada pelo perímetro oficial. Esta cidade reflete sua sociedade, reflete as influências sofridas em seu processo construtivo e mostra um tecido urbano marcado por áreas dinâmicas e por vazios que expressam a dinâmica urbana local no momento em que deslocam os olhares para os pontos luminosos da cidade.

\section{ALÉM DAS ÁREAS DINÂMICAS...}

O espaço urbano de Jataí não se configura isoladamente, está inserido no contexto de sua microrregião, do estado, país e até mesmo do mundo.

Para conhecer este espaço não basta apenas observá-lo em sua forma bruta, como nos é visivelmente apresentado. Entender a formação desta paisagem, que nos traz encontros e desencontros, é tarefa que passa pela atividade de interpretação daquilo se mostra em primeiro plano. Desta forma, foi necessário desvelar este espaço, tentando enxergar além do visível. É nesta atividade que o olhar de investigador, de cientista, deve estar atento para o fato de que o visível nem sempre é o real.

O visível não mostra a desigualdade observada neste espaço, que parte dos primórdios da história do município, parte da gestação das grandes fazendas formadas na região para desenvolvimento da agropecuária e liga-se diretamente ao contexto econômico atual e à moderna agropecuária. Esta última imprime de forma mais marcante as características urbanas atuais. O aglomerado urbano apresenta uma relação íntima com a implementação da moderna agropecuária do município e seu entorno, o que traz desenvolvimento à região, mas, por outro lado, deixa efeitos colaterais como o inchaço dos centros urbanos e a desigualdade na distribuição de renda.

Nas origens do município, o que nos remete a 1836, quando chegam os primeiros ocupantes da região, a realidade atual não poderia ser imaginada. A atividade agropecuária tradicional não seria combustível suficiente para dar forças ao motor dinâmico que atualmente move a região. Necessitava-se de uma transformação, o que ocorre num período mais contemporâneo. É, sobretudo, a partir da década de 1970 que se percebe mudanças significativas no uso da terra da região. 
Nestas mudanças o município experimentará crescimentos significativos, destacando-se a produção de grãos para exportação, numa dependência do global refletido localmente. Também, como fruto das mudanças ocorridas, emerge a necessidade de controle da ocupação do solo urbano para que os mais de $90 \%$ da população do município residente na área urbana não se constituam em um problema a mais para a administração pública.

É nesta dinâmica que Jataí percebe um grande crescimento de sua área urbana com a implantação de vários loteamentos, sendo que sua maioria parte do princípio capitalista de lucro. A ação do capital incrementa-se e faz-se presente, de forma opressora, na vida do indivíduo de menor renda que não consegue adquirir uma parcela do solo urbano.

Tais ações trazem conseqüências para a cidade formando um espaço fragmentado, o que pode ser percebido pela Figura 10, e caro para os contribuintes. Os vazios urbanos, na espera de uma valorização perceptível a cada dia que passa, sobretudo pelo observado processo de "expansão do centro da cidade”, desloca um grande contingente populacional para a periferia pobre. Neste processo são levados equipamentos públicos que, mesmo sendo, em muitos casos, em número e qualidade inferior às necessidades locais, dão subsídios à valorização das áreas intermediárias (salienta-se que tais equipamentos já deveriam estar presentes antes da chegada dos habitantes destas áreas).

O arranjo urbano em questão é, assim, contraditório. Espaço contraditório, sociedade contraditória. Alguns vão para a periferia por imposição (Figura 11), outros por opção. A sociedade se diferencia até mesmo pela composição das áreas periféricas, uma vez que parte da nova elite optou por se cercar de altos muros em seu condomínio fechado (Figura 12), “longe” dos problemas da sociedade construída pelo sistema que lhes dá condições privilegiadas.

São estes alguns desencontros percebidos na análise da ocupação desta parcela do Cerrado goiano. Com certeza a vegetação original, com seus galhos retorcidos, encontrada em tempos remotos, era mais harmônica do que a cidade construída após sua derrubada. As árvores do Cerrado formavam um espaço coeso 


\section{AATELIÊ GEOGRÁFICO

expressando uma união natural. A cidade forma um espaço fragmentado, espaço construído sem a harmonia necessária à fluidez esperada em uma moderna sociedade.

Figura 11: Jataí-GO: Área urbana - vista parcial - Setor Jacutinga

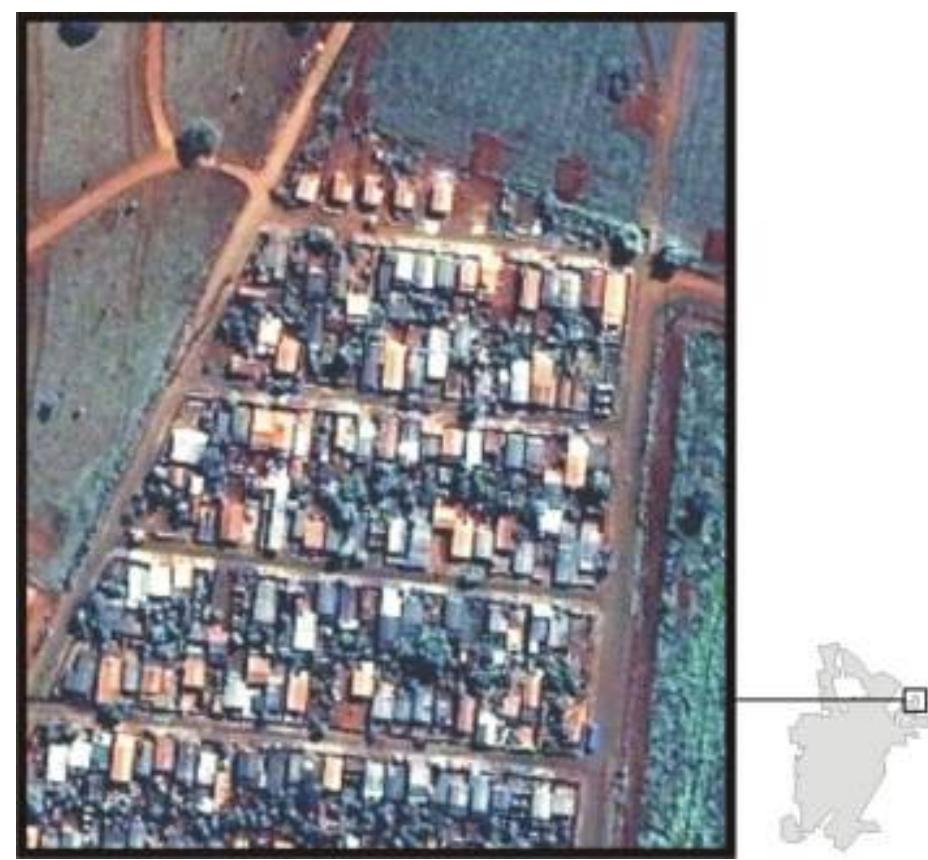

Fonte: Imagem de Satélite - JATAI-GO (2004): Mapas Cadastrais.

Inserir aqui a Figura 12: Jataí-GO: Área urbana - vista parcial - Região Oeste Condomínio Residencial Barcelona

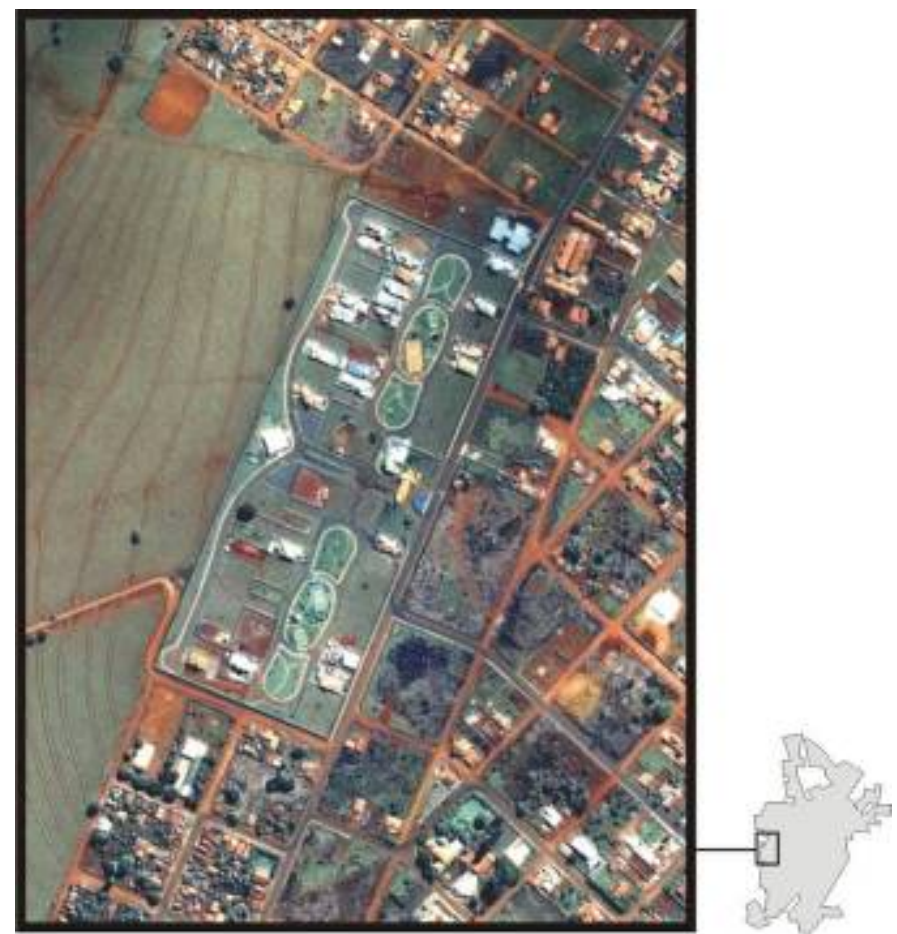

Fonte: Imagem de Satélite - JATAI-GO (2004): Mapas Cadastrais. 
Se o espaço não é harmônico, é dinâmico. Isso é verificado pelo movimento promovido com implantação das atividades econômicas principalmente a partir da década de 1970 (Tabela 2, Quadro 1 e Figuras 4 a 9). Numa cidade de características basicamente agropecuárias o setor de serviços aparece em primeiro lugar, em número de estabelecimentos implantados, num desenvolvimento que revela o movimento promovido pelas riquezas locais e que indica novos rumos para a economia da cidade. Este dinamismo dá-se também pela consolidação do espaço urbano (Figura 2) e pela gestação das áreas dinâmicas em questão (Figura 10). Partindo do núcleo urbano original ocorre uma expansão na busca de mais e melhores espaços, o que consolida a expansão do centro da cidade dando, provavelmente, sustentação para o posterior surgimento de um novo centro, ou mesmo de setores especializados em serviços específicos.

Da chegada da fronteira agrícola aos dias atuais houve grande transformação. Hoje a ocupação é organizada e direcionada pelo capital, ou melhor, pelos agentes do capital, por indivíduos a serviço do capital. A cidade dependente do pequeno centro original, ao redor da praça da igreja e dos casarões da velha elite (Figura 13), não mais existe. Não que esta cristalização tenha se dissolvido no espaço-tempo, embora parte da memória arquitetônica tenha sido destruída. O que ocorre atualmente é uma remodelação do "antigo” em função do “novo”. Dá-se nova função às velhas formas: o antigo casarão hoje é museu e serve ao turista; na praça é raro encontrar vizinhos conversando, periodicamente há uma feira que reúne principalmente a juventude movida por uma música nada tradicional.

É este o arranjo socioespacial existente. A sociedade se espacializou. Se espacializa a cada dia. Impõem suas marcas. Hoje este processo já tem certo direcionamento. São determinações do Plano Diretor Urbano que de certa forma moldam as novas áreas, à medida que suas exigências são cumpridas. Todavia, os erros pretéritos ficam consolidados como um aviso para que o caminho a seguir seja diferente, e isso depende do aproveitamento das potencialidades ofertadas pela sociedade, fundamentalmente a do saber científico. Cabe aos dirigentes públicos saber 


\section{AATELIÊ GEOGRÁFICO

fazer uso destas potencialidades de forma a promover o real desenvolvimento anteriormente comentado.

Inserir aqui a Figura 13: Museu Histórico de Jataí - Antigo Casarão no centro da Cidade

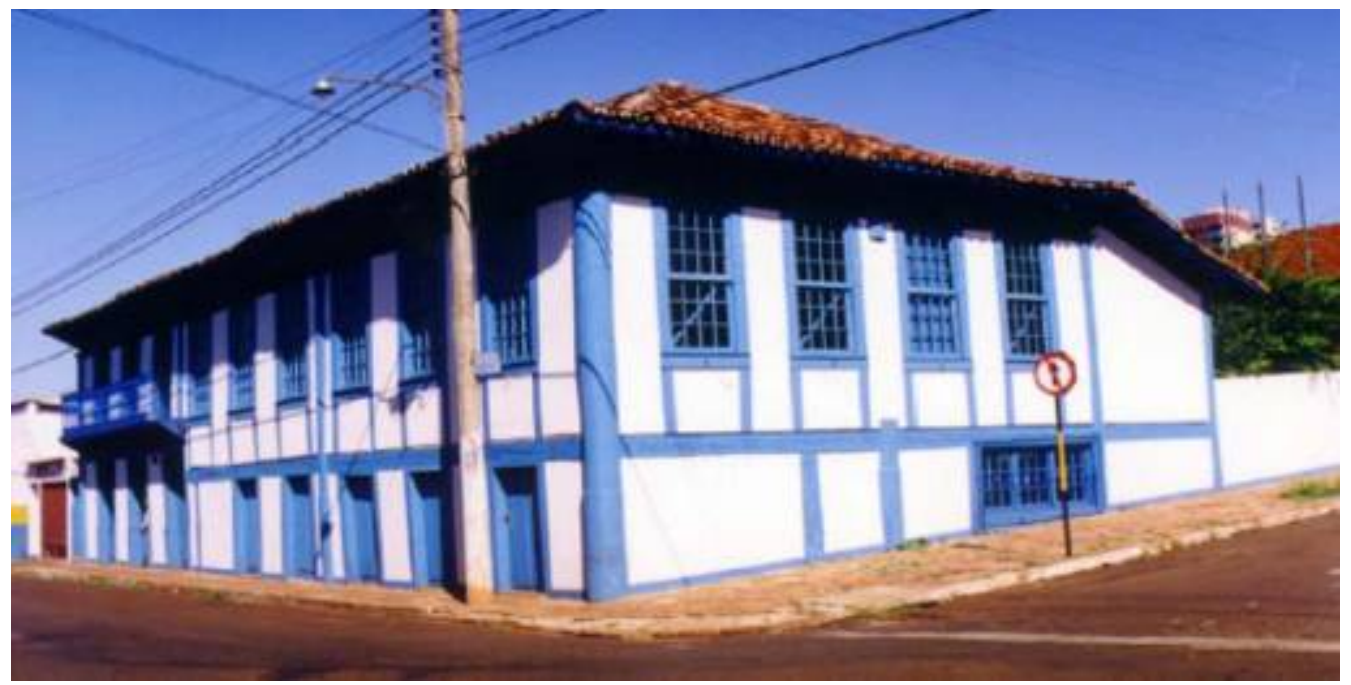

Fonte: JATAI-GO (2004a) - Dossiê de Jataí - Foto: Gênio Eurípedes

Com tantas alterações, movimentos e dinâmicas próprias ao crescimento da cidade o espaço urbano responde às ações sofridas. A elevada taxa de urbanização não se restringe a números. São indivíduos que necessitam de um espaço no arranjo urbano. Os migrantes chegam para dar mais pressão na demanda por habitações, por espaço, por serviços públicos. A população rural não é mais rural, aglomera-se na cidade e não se torna urbana, pois guarda consigo características, traços, costumes próprios do campo e, talvez, o desejo de para ele retornar. Todos estes atores fazem parte de um teatro dirigido pelo capital. Quanto aos papéis por eles exercidos não se sabe ao certo , dependerá da conjuntura atual, local e global.

A cidade responde a todos com respostas que nem sempre agradam. Ou ainda, agradam alguns, desagradam outros tantos. A cidade responde com a expansão urbana, com os parques ecológicos, com os serviços que crescem a cada dia, com habitações populares gratuitas, com 0 assistencialismo estatal às famílias desempregadas - um prêmio àqueles que não conseguiram por méritos próprios sobreviver dignamente. 
São várias respostas. Todas, porém, condicionadas a vontades superiores e que geralmente visam atender interesses individuais num processo de socialização dos prejuízos e privatização dos lucros. Mas, prejuízo ou lucro de quê? Do conjunto urbano que se transformou numa empresa lucrativa.

Hoje se fabrica uma imagem da cidade para ser vendida externamente. No entanto, não se divulga a desigualdade social; não se divulga a situação dos mais de $20 \%$ da população encontrados na faixa da pobreza. Não se divulga que os $20 \%$ mais ricos detêm cerca de 64\% da renda local (SILVA, 2005, p.97).

Não há espaço na guerra dos lugares para um marketing mal feito. Estudos mostram que município oferece grandes potencialidades ${ }^{2}$. Há, todavia, de se promover uma equalização social para que não seja necessário “maquiar” a cidade para promover seu desenvolvimento. Com mais justiça social, e condições iguais a todos, ocorrerá no espaço urbano a cristalização desta aspirada sociedade. A “cidade ideal” será, desta forma, resultado de ações fundamentalmente sociais. Será o reflexo da valorização da maior parte da sociedade que atualmente está tão esquecida.

As melhorias nas condições urbanas locais passam pelo desenvolvimento econômico da cidade, uma vez que ambos estão intimamente ligados. As décadas de 1970 a 1990 apresentam significativo crescimento econômico e, por conseqüência, um maior dinamismo ao conjunto urbano. Neste período, fundamentalmente nas décadas de 1980 e 1990, o espaço urbano passa a se estruturar de forma mais consistente, seja pela consolidação de um centro econômico com destaque para o setor de serviços, seja pela ocupação de áreas intermediárias entre o centro e a periferia. Fomentar a economia local, mas com olhos bem abertos para que os efeitos retidos sejam somente os positivos, torna-se crucial para a consolidação de Jataí nos âmbitos locais e regionais.

A cidade, concentrando serviços, atrai para si todo um conjunto de fatores positivos ao desenvolvimento local. Através da estruturação das infra-estruturas fundamentais ao bom andamento das atividades urbanas Jataí poderá fortalecer seu papel de influência na região Sudoeste de Goiás. Oferecer serviços de qualidade no que tange à formação - com um sistema de ensino que atenda a demanda, especialmente em

\footnotetext{
${ }^{2}$ Conferir por exemplo MELO (2003) e SILVA(2005)
} 
nível superior; à cultura e lazer - investindo no turismo local e nas suas potencialidades; ao transporte urbano - atendendo toda a malha urbana; à saúde, segurança e outros é fundamental numa cidade que se mostra interessada em "competir" na guerra dos lugares.

\section{CONSIDERAÇÕES FINAIS}

As transformações ocorridas em Jataí nos últimos anos revelam que ações públicas bem direcionadas podem alterar positivamente a realidade urbana. No entanto, deixam o alerta para que estas ações sejam tomadas de forma consciente e com embasamento técnico-científico adequado de forma a atender a sociedade como um todo, e não apenas uma parcela, promovendo o tão sonhado “desenvolvimento real” e uma melhoria na qualidade de vida dos jataienses.

Embora os problemas ainda sejam muitos, necessitando de atenção constante da sociedade, considera-se que houve uma evolução do tecido urbano. Fato este que aumenta a responsabilidade dos governantes frente a esta realidade que em muito se diferencia dos tempos remotos. Jataí tem hoje um espaço urbano consolidado. A capacidade de transformação da sociedade contemporânea é alta e veloz. A gestão urbana não pode ficar atrás.

Não pretendemos, com estas breves e preliminares observações, chegar a conclusões imediatas de um tema que envolve tantas outras variáveis. Nosso objetivo é demonstrar alguns pontos relevantes ao estudo do espaço urbano de Jataí e de sua dinâmica. Fornecer subsídios, promover debates e discussões por uma ocupação mais racional e pautada em princípios que levem a uma melhor qualidade de vida da população local constituem também o alvo do presente trabalho.

\section{REFERÊNCIAS}

CASTELLS, Manuel. A questão urbana. Tradução de Arlene Caetano. Rio de Janeiro: Paz e Terra, 1983. 590p.

JATAÍ-GO. Secretaria de Obras e Urbanismo. Divisão de Planejamento Urbano. Jataí: Lotes vagos. 1995. 
Secretaria de Obras e Urbanismo. Divisão de Planejamento Urbano.

Plano Diretor Urbano. 2001.

. Secretaria de Obras e Urbanismo. Divisão de Planejamento Urbano. Plano Diretor Urbano. 2003.

. Secretaria de Obras e Urbanismo. Divisão de Planejamento Urbano. Mapas cadastrais. 2003a.

. Secretaria de Obras e Urbanismo. Divisão de Planejamento Urbano. Mapas cadastrais. 2004.

Superintendência de Indústria, Comércio e Turismo. Dossiê de Jataí.

2004a. Disponível em: < www.jatai.go.gov.br > Acesso em: 26 de jan., 2004.

. Secretaria de Gestão Fiscal. Programa de cadastramento de atividades econômicas. 2004b. Jataí: [s.n.], 2004.

. Secretaria de Obras e Urbanismo. Divisão de Planejamento Urbano.

Jataí: Lotes vagos. 2004c.

Secretaria de Gestão Fiscal. Relatório das atividades econômicas cadastradas. 2004d. Jataí: [s.n.], 2004.

LEFEBVRE, Henri. A Cidade do Capital. Tradução de Maria Helena Rauta Ramos e Marilena Jamur. Rio de Janeiro: DP\&A, 1999. 180p.

MELO, N. A. Interação campo-cidade: a (re)organização socioespacial de Jataí no período de 1970 a 2000. 2003, 179 p. Dissertação (mestrado) - Universidade Federal de Uberlândia, Instituto de Geografia, Uberlândia, 2003.

PNUD/IPEA/FUNDAÇÃO JOÃO PINHEIRO. Atlas do desenvolvimento humano no Brasil. Versão 1.0.0: ESM Consultoria, 2003.

SANTOS, Ângela Moulin S. Penalva. Reestruturação espacial e dinâmica econômica. Trabalhos \& Publicações NEMESIS, 1998. Disponível em <www.nemesis.org.br> Acesso em: 05 de Abr. 2007.

SANTOS, Milton. A Urbanização Brasileira. São Paulo: Editora Hucitec, 1993.

SILVA, Márcio Rodrigues. Encontros e desencontros: estudo do espaço urbano de Jataí-GO. 2005, 113p. Dissertação (Mestrado em Geografia) -Universidade Federal de Goiás, Instituto de Estudos Sócio-Ambientais, Goiânia, 2005

SOUZA, Marcelo Lopes de. ABC do desenvolvimento urbano. Rio de Janeiro: Bertrand Brasil, 2003. 190p.

Recebido para publicação em novembro de 2007

Aprovado para publicação em dezembro de 2007 